DOI: https://doi.org/10.21009/JPEB.004.2.2

\title{
PENGARUH OTORITAS PENGAMBILAN KEPUTUSAN TERHADAP EFEKTIVITAS PENGELOLAAN SEKOLAH DI KOTA MATARAM
}

\author{
Abdul Kadir \\ Dinas Pendidikan Kota Mataram, Nusa Tenggara Barat \\ dirson35@yahoo.com
}

\begin{abstract}
ABSTRACK
The school management effectiveness is significantly influenced by the role of local leaders, the school committee who runs its roles functionally, positive supports delivered by virtual teams and effective decisions made by the principal. 100 principals and 300 senior teachers of primary schools had filled out questionnaires. The data then analyzed statistically by applying path analysis. Research reveals that there are positive direct effects among the variables tested and it can be viewed from two major paths. Firstly, the school management effectiveness is directly influenced by the roles of local leaders, functioned school committee, supports by virtual team and decision making. Secondly, decision making directly influenced also by the roles of local leaders, functioned school committee, and supports by virtual team. It implies that the school management proved its effectiveness when attained direct positive roles from local leaders, functioned school committee, supports by virtual team and effective decision making handled by the principal.
\end{abstract}

Key Words: School Management, Local Leaders, School Committee, Virtual Teams, Decision Making.

\begin{abstract}
ABSTRAK
Efektivitas pengelolaan sekolah sangat dipengaruhi oleh peran pemimpin lokal, komite sekolah yang menjalankan fungsinya secara fungsional, dukungan positif yang disampaikan oleh tim virtual dan keputusan efektif yang dibuat oleh kepala sekolah. 100 kepala sekolah dan 300 guru senior di sekolah dasar telah mengisi kuesioner.Data kemudian dianalisis secara statistic dengan menerapkan analisis jalur.Penelitian menunjukkan bahwa ada efek langsung positif diantara variabel yang diuji dan dapat dilihar dari dua jalur utama. Pertama, efektivitas pengelolaan sekolah secara langsung dipengaruhi oleh peran pemimpin daerah, komite sekolah yang difungsikan, didukung oleh tim virtual dan pengambilan keputusan. Kedua, pengambilan keputusan secara langsung juga dipengaruhi oleh peran pemimpin daerah, komite sekolah yang difungsikan, dan didukung oleh tim virtual. Ini menyitratkan bahwa manajemen sekolah membuktikan keefektifannya bila memperoleh peran positif langsung dari pemimpin daerah, komite sekolah yang difungsikan, didukung oleh tim
\end{abstract}


virtual dan pengambilan keputusan yang efektif yang ditangani oleh kepala sekolah.

Kata kunci: Manajemen Sekolah, Pemimpin Lokal, Komite Sekolah, Tim Virtual, Pengambilan Keputusan.

\section{PENDAHULUAN}

Keberhasilan pengelolaan sebuah sekolah banyak ditentukan oleh keputusan yang diambil kepala sekolah. Keputusan-keputusan kecil maupun besar akan menentukan langkah dan arah penyelenggaraan persekolahan selanjutnya. Semua itu membutuhkan rasionalitas yang cukup dari kepala sekolah untuk membuat keputusan-keputusan penting dalam rangkaian pekerjaannya.

Pengambilan keputusan tersebutturut pula dipengaruhi faktor-faktor lain seperti local leaders yang dengan kekuasaan dan pengaruhnya turut berperan menjadi pemicu bagi terselenggaranya pengelolaan pendidikan yang baik. Virtual team yang memanfaatkan kemajuan ilmu dan teknologi guna memberikan dukungan berupa premis-premis atau data kongkrit tentang situasi terkini sesuai dengan pengalaman dan pemahamannya. Serta komite sekolah sebagai mitra dengan empat fungsinya turut mewarnai pengambilan keputusan kepala sekolah yang sehat dan rasional. Namun demikian, keberadaan mereka bagaikan dua sisi mata uang. Sisi sejatinya, intensitas dukungan tersebut berpotensi membangun kapasitas sekolah dalam mencapai tujuannya dengan sukses dan efektif. Pada sisi lain, kehadiran mereka justru menjadi bumerang bagi sekolah karena memberikan tekanan-tekanan yang kadang bertentangan dengan tujuan sekolah.

Berangkat dari fenomenafenomena di atas, pengkajian secara mendalam tentang pengelolaan sekolah yang efektif sangat perlu dilakukan khususnya dalam kaitannya dengan pengambilan keputusan kepala sekolah. Demikian pula pengaruh faktor-faktor lain seperti pemimpin lokal yang dengan kekuasaan dan pengaruhnya turut menjadi pemicu bagi terselenggaranya pengelolaan pendidikan yang baik.

\section{KAJIAN TEORITIK}

Munculnya elit-elit lokal yang sekaligus sebagai pemimpinpemimpin lokal yang memanfaatkan kekuasaan dan pengaruhnya turut bermain dalam bidang pendidikan (Guthrie, 2010). Pemimpinpemimpin lokal baik pemimpin lokal formal maupun pemimpin lokal informal terkadang membuat kepala sekolah kebingungan dalam membuat keputusan ketika terlibat di sekolah dengan kepentingan pribadi (Taruna, 2002).

Kondisi ini bertentangan dengan peran positif local leadersyang efektif sebagaimana dikemukakan oleh Gamage (David, 2006) bahwa participation must focus on the creation of new school communities that challenge the 
strategies for institutional development adopted in the past; atau membantu mengembangkan kualitas hidup individu dan masyarakat (Blair, 2001); membantu menciptakan kesepakatan tentang sasaran, prioritas dan strategis(Yulk, 2003); kepemimpinan lokal hendaklah mampu menceritakan (telling), menjual (selling), berpartisipasi (participating) dan mendelegasikan (delegating) (Brophy, 2007); bahkan memainkan peran dalam hal-hal political, managerial and community (Kerslake, 2007).

$\mathrm{Di}$ sisi lain, fungsi komite masih belum maksimal di beberapa sekolah. Penyelenggaraan Manajemen Berbasis Sekolah masih terasa timpang. Setelah digulirkannya dana Bantuan Operasional Sekolah, fungsi komite sekolah hanya berupa stempel dan tanda tangan. Hal ini disebabkan karena selama ini komite sekolah hanya terlibat pada aspek finansial melalui iuran komite sekolah. Terlebih lagi di Kota Mataram yang telah memberlakukan pendidikan gratis. Komite Sekolah hanya hadir ke sekolah ketika diundang rapat, atau untuk tanda tangan laporan penggunaan dana BOS. Keberadaan Komite Sekolah yang demikian sangat bertentangan dengan undangundang. Sejatinya, komite sekolah berperan aktif selain sebagai advisory agency, controlling dan supporting agency juga sebagai mediatoryang dapat membantu kepala sekolah dalam mengambil keputusan-keputusan strategis (Depdiknas, 2002) ; (Sumintono, 2007); (Mulyasa, 2007), dan (Ausaid, 2010).
Demikian pula menurut Davis (1998) bahwa fungsi komite sekolah dapat berupa hal-hal yang lebih luas yaitu meningkatkan penggunaan segala sumberdaya yang ada. Sedangkan menurut Arsteyn (1966) bahwa bentuk partisipasi dapat disalurkan melalui negosiasi antara pemegang kekuasaan dan masyarakat. Sepakat memikul tanggung jawab dalam perencanaan dan pengambilan keputusan secara bersama-sama. Aturan ditentukan melalui mekanisme take and give, sehingga diharapkan tidak mengalami perubahan secara sepihak. Hal ini dapat ditemukan pula dalam Covey (1994) bahwa kemitraan adalah jenis hubungan antardua atau beberapa pihak dengan sifat-sifat dasar (jangka panjang, berorientasi pemecahan persoalan bersama/tujuan bersama, dilandasi nilai-nilai luhur dan saling bergantung).

Selanjutnya, tim kerja yang solid akan memberikan arahan yang memadai bagi kepala sekolah dalam mempertimbangkan, menentukan, dan memutuskan setiap kebijakan yang berkenaan dengan pengelolaan sekolah. Virtual teamyang saling berhubungan melalui media elektronik. Media informasi dan telekomunikasi seperti situs-situs jejaring sosial seperti facebook, tweeter, blackberry messager, yahoo messager,whatsapp dan lainnya. Pola komunikasi virtual yang paling banyak dan sering dilakukan oleh kepala-kepala sekolah di Kota Mataram adalah dengan menggunakan pesawat telepon dan telepon seluler. Komunikasi dengan alat-alat 
elektronik ini selain mudah dioperasikan, juga biaya murah. Penggunaan alat komunikasi yang berbasis jaringan internet dimanfaatkan untuk komunikasi tertulis dan berkaitan dengan data yang perlu dijadikan rujukan. Kebiasaan baik ini akan menjadi salah satu wadah potensial untuk menggerakkan opini dan kepedulian terhadap dunia pendidikan. Bagi kepala sekolah dapat menjadi masukan berharga dalam upayanya mengumpulkan premis-premis yang turut menentukan dalam pengambilan keputusan yang tepat terkait dengan pengelolaan sekolah yang menjadi tanggung jawabnya.

Peran local leaders, fungsi komite sekolah dan dukungan virtual teams membantu kepala sekolah dalam membuat keputusan. Keputusan-keputusan besar maupun kecil yang terkait pengelolaan sekolah. Keputusan yang baik, kuat dan sehat hendaknya mendapat dukungan instrumental positif dari variabelvariabel lain. Kepala sekolah tidak akan dapat membuat keputusan yangmemadai dan kuat bilamana mendapat tekanan dari berbagai pihak bahkan kepala sekolah cenderung melanggar keputusan yang telah disepakati sebelumnya.

\begin{tabular}{ll}
\multicolumn{2}{c}{ Sebagaimana dikemukakan } \\
oleh Hoy dan \\
2001)bahwa
\end{tabular}
keputusan adalah kegiatan kepala sekolah dalam melaksanakan memutuskan sesuatu dengan terlebih dahulu mengikuti langkahlangkah seperti memahami landasan pemilihan alternatif, menetapkan tujuan dan sasaran, melakukan pemecahan masalah, menetapkan model dan metode, mengevaluasikualitas pengambilan keputusan dan menggunakan strategi pengambilan keputusan sehingga keputusannya mempengaruhi efektivitas pengelolaan sekolah.

Pengambilan keputusan pada dasarnya merupakan salah satu komponen penting dan sangat fundamental dalam manajemen pendidikan serta berpengaruh pada keberhasilan pendidikan (Robbins, 1994). Hess dan Siciliano (Hess, 1996) mengemukakan bahwa "decision making is the process of selecting and implementing alternatives consistent with a goal." Newstrom (Davis, 1998), mengemukakan bahwa "the rational choice theorists believe in the universality of the self-interested and utility maximizing (rational) individual decision makers. However, this core assumption is modified and qualified in many versions of rational choice. Particularly, the institutional rational choice theorists emphasize the role of social structures (institutions) in constricting the rationality of individual choices and behaviors".

Sedangkan menurut Allison dan Zelikov (Allison, 1999) bahwa keputusan-keputusan yang biasanya dibuat oleh organisasi bagi si individu, yaitu: menetapkan fungsinya, yaitu ruang lingkup serta sifat umum dari pada tanggung jawabnya; membagikan wewenang, yakni menetapkan siapa yang harus diberi kekuasaan untuk membuat keputusan lebih lanjut bagi si individu; dan menentukan batasbatas lainnya terhadap pilihannya 
yang diperlukan untuk mengkoordinir kegiatan-kegiatan dari beberapa individu di dalam organisasi itu.

Ahli lain berpendapat bahwa pengambilan keputusan merupakan "the process of generating and valuating alternatives and making choices among them," (Mondy, 1988). Sementara itu, Schermerhorn, Hunt dan Osborn (2005) mengemukakan bahwa "decision making is the process of choosing a course of action for dealing with a problem or opportunity." Luthans (Luthans, 1995) juga mengemukakan bahwa "decision making is almost universally defined as choosing between alternatives" atau "the selection of prefered course of action from two or more alternatives." Sedangkan Salusu (1996) memberikan batasan bahwa pengambilan keputusan sebagai proses memilih suatu alternatif, cara bertindak dengan metode yang efisien sesuai situasi. Dengan demikian dalam memilih suatu alternatif atau gabungan alternatif harus dipilih solusi yang mempunyai kerugian paling sedikit dan paling menguntungkan serta tidak menimbulkan masalah baru.

Terakhir, efektivitas pengelolaan sekolah merupakan hasil kerja civitas akademik di sekolah dan dipertanggungjawabkan oleh kepala sekolah sebagai salah satu bentuk unjuk kerja. Thelbert dan Roe (Roe, 1986) dengan tegas mengatakan bahwa the principal was the person identified as being responsible for exerting this leaderships. Hoy dan Miskels (Hoy, 2001) mengklaim bahwa cara memandang efektif tidaknya sebuah sekolah tergantung sungguh pada patron sekolah. Sebab, sebuah sekolah dibandingkan dengan sekolah lainnya memiliki tingkat kesuksesan yang berbeda, walaupun dengan jumlah siswa yang sepadan. Guthrie dan Schuermann(Guthrie, 2010) menulis bahwa semua yang ditunjukkan oleh sekolah tersebut adalah prestasi yang juga merupakan value added (nilai tambah) bagi sekolah dalam upayanya meningkatkan kualitas pengelolaan dan hasil pendidikan di sekolah.

Sedangkan hasil penelitian Porter, Goldring dan Murphy(Porter, 2006) mengemukakan bahwa keberhasilan sebuah pengelolaan satuan pendidikan ditentukan oleh ketercapaian memenuhi standar yang tinggi pada hasil belajar siswa, kurikulum yang dikembangkan dan dilaksanakan dengan teliti, kualitas pembelajaran, budaya belajar, koneksi dengan masyarakat eksternal, akuntabilitas kinerja yang sistematis, perencanaan yang memadai, penerapan yang bertujuan, dukungan dari berbagai pihak, advokasi, komunikasi dan monitoring yang dilakukan secara terus-menerus. Senada dengan pendapat tersebut, efektivitas yang ditinjau dari segi produk didefinisikan sebagai sejauh mana sebuah sekolah mewujudkan tujuantujuannya(Robbins, 1994).

Berdasarkan pengertian tersebut efektivitas sebagai produk didasarkan pada tingkat pencapaian tujuan suatu organisasi maupun lembaga. Sementara itu, Steers 
(1980) memandang efektivitas organisasi dari segi proses.

Efektivitas sebagai suatu proses berarti melaksanakan pekerjaan dengan benar. Maksudnya, efektivitas sebagai proses menggambarkan bagaimana seorang pimpinan dapat memanfaatkan segala sumberdaya dan fasilitas yang ada atau dimiliki agar personil dapat melaksanakan tugas yang lebih sederhana secara spesifik. Stonner, Freeman dan Gilbert (Stoner, 1996) mengatakan bahwa efektivitas sebagai kapasitas suatu organisasi untuk memperoleh dan memanfaatkan sumberdayanya yang langka dan berharga sepandai mungkin untuk mengejar tujuan operasi dan operasionalnya.

\section{METODOLOGI PENELITIAN}

Pendekatan yang digunakan dalam penelitian ini adalah penelitian kuantitatif dengan jenis penelitian asosiatif yang bermakna bahwa penelitian ini menganalisis faktor-faktor dominan yang mempengaruhi pengambilan keputusan kepala sekolah dalam kaitannya dengan efektivitas pengelolaan sekolah di Kota Mataram. Data diperoleh dari hasil angket yang sudah diujicobakan sebelumnya dari sampel 100 orang kepala sekolah dan 300 orang guru sebagai rater. Data hasil penelitian dianalisis dengan menggunakan analisis statistik parametrik model path analysis. Tingkat signifikansi koefisien jalur digunakan uji t. Sebelum pengujian hipotesis, dilakukan uji persyaratan analisis; uji normalitas, regresi, dan linieritas. Analisis data dilakukan pada taraf signifikansi 0,05 dan 0,01.

\section{HASIL DAN PEMBAHASAN}

Hasil pemaparan statistik atas beberapa variabel yang diukur atau diamati dalam penelitian yang dilakukan sebelum perhitungan analisis jalur berupa ukuran pemusatan data yang meliputi: nilai rata-rata hitung, modus dan median, serta ukuran penyebaran data yang meliputi range, standar deviasi dan varians data disampaikan dalam tabel berikut.

Tabel 1. Rangkuman Statistik Sederhana Setiap Variabel

\begin{tabular}{l|r|r|r|r|r}
\hline Deksripsi & $\mathrm{Y}$ & $\mathrm{X}_{4}$ & $\mathrm{X}_{1}$ & $\mathrm{X}_{2}$ & $\mathrm{X}_{3}$ \\
\hline $\mathrm{n}$ Valid & 100 & 100 & 100 & 100 & 100 \\
\hline Mean & 127,18 & 129,146 & 114,37 & 104,22 & 102,57 \\
\hline Median & 126,50 & 128,00 & 113,46 & 103,72 & 105,50 \\
\hline Modus & 124,50 & 123,91 & 109,75 & 101,50 & 103,93 \\
\hline Std. Deviasi & 18,52 & 17,76 & 16,08 & 19,11 & 3,64 \\
\hline Varian & 343,02 & 315,51 & 258,02 & 361,69 & 13,25 \\
\hline Maksimum & 166 & 168 & 150 & 144 & 109 \\
\hline Minimum & 75 & 83 & 69 & 50 & 94 \\
\hline Range & 91 & 85 & 81 & 94 & 15 \\
\hline
\end{tabular}

Perhitungan hubungan kausal antarvariabel penelitian diketahui bahwa semua variabel eksogen dalam penelitian ini secara nyata berpengaruh langsung positif terhadap variabel endogen. 
Pertama, peran local leaders $\left(\mathrm{X}_{1}\right)$ berpengaruh langsung positif terhadap efektivitas pengelolaan sekolah (Y) sebesar $=0,22$. Kedua,fungsi komite sekolah $\left(\mathrm{X}_{2}\right)$ berpengaruh langsung positif terhadap efektivitas pengelolaan sekolah $(\mathrm{Y})$ sebesar $=0,23$. Ketiga, dukungan virtual team $\left(\mathrm{X}_{3}\right)$ berpengaruh langsung positif terhadap efektivitas pengelolaan sekolah $(\mathrm{Y})$ sebesar $=0,22$. Keempat, pengambilan keputusan kepala sekolah $\left(\mathrm{X}_{4}\right)$ berpengaruh langsung positif terhadap efektivitas pengelolaan sekolah $(\mathrm{Y})$ sebesar $=$ 0,54 . Kelima,peran local leaders $\left(\mathrm{X}_{1}\right)$ berpengaruh langsung positif terhadap pengambilan keputusan kepala sekolah $\left(X_{4}\right)$ sebesar $=0,32$. Keenam,fungsi komite sekolah $\left(\mathrm{X}_{2}\right)$ berpengaruh langsung positif terhadap pengambilan keputusan kepala sekolah $\left(X_{4}\right)$ sebesar $=0,26$, dan terakhir, dukungan virtual team $\left(\mathrm{X}_{3}\right)$ berpengaruh langsung positif terhadap pengambilan keputusan kepala sekolah $\left(X_{4}\right)$ sebesar $=0,22$. Hasil perhitungan tersebut ditunjukkan dalam tabel berikut:

Tabel 2. Rangkuman Koefisien Jalur Model Struktural Penelitian

\begin{tabular}{|c|c|c|c|c|c|c|}
\hline \multirow{2}{*}{\multicolumn{2}{|c|}{ Jalur }} & \multirow{2}{*}{$\begin{array}{l}\text { Koefisien } \\
\text { Jalur }\end{array}$} & \multirow[b]{2}{*}{$t_{\text {hitung }}$} & \multicolumn{2}{|c|}{$t_{\text {tabel }}$} & \multirow[b]{2}{*}{ Hasil Uji } \\
\hline & & & & \multirow{2}{*}{$\begin{array}{c}\alpha= \\
0,05 \\
1,66\end{array}$} & \multirow{2}{*}{$\begin{array}{c}\alpha= \\
0,01 \\
2,37\end{array}$} & \\
\hline $\mathrm{X}_{4} \mathrm{X}_{1}$ & $\rho_{41}$ & $0,32^{* *}$ & 3,55 & & & Berpengaruh langsung positif \\
\hline $\mathrm{X}_{4} \mathrm{X}_{2}$ & $\rho_{42}$ & $0,25^{*}$ & 2,70 & 1,66 & 2,37 & Berpengaruh langsung positif \\
\hline$X_{4} X_{3}$ & $\rho_{43}$ & $0,21^{* *}$ & 2,24 & 1,66 & 2,37 & Berpengaruh langsung positif \\
\hline$Y X_{1}$ & $\rho_{\mathrm{y} 1}$ & $0,23^{* *}$ & 3,48 & 1,66 & 2,37 & Berpengaruh langsung positif \\
\hline $\mathrm{YX}_{2}$ & $\rho_{\mathrm{y} 2}$ & $0,23^{*}$ & 3,96 & 1,66 & 2,37 & Berpengaruh langsung positif \\
\hline$Y X_{3}$ & $\rho_{y 3}$ & 0,25 & 3,87 & 1,66 & 2,37 & Berpengaruh langsung positif \\
\hline $\mathrm{YX}_{4}$ & $\rho_{\mathrm{y} 4}$ & $0,54^{* \prime}$ & 8,98 & 1,66 & 2,37 & Berpengaruh langsung positif \\
\hline
\end{tabular}

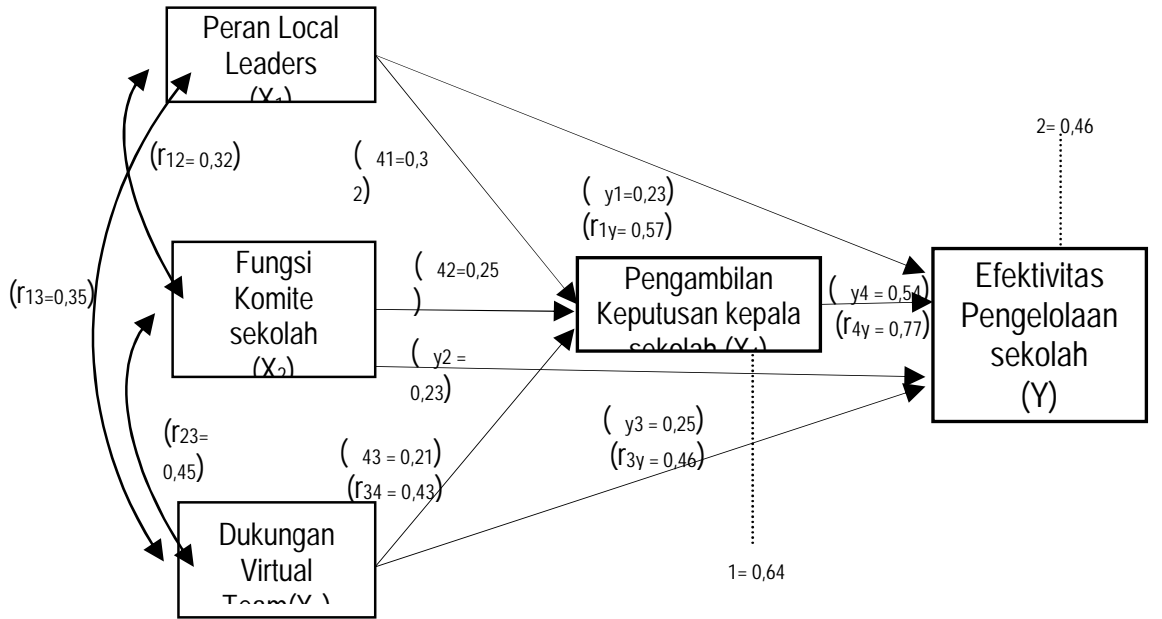

\section{Gambar 1. Model Empirik Hubungan Struktural Antarvariabel berdasarkan Hasil Perhitungan Analisis Jalur}


Seperangkat pembuktian
empirik di atas setidaknya
menyiratkantujuh poin utama.
Pertama, peran local leaders
berpengaruh langsung terhadap
efektivitas pengelolaan sekolah,
dimana peran local leaders dalam
mempengaruhi, mengarahkan, dan
membimbing, mengarong
dalam menggerakkan
kepemimpinan sekolah berpengaruh
langsung terhadap efektifnya
pengelolaan sekolah. Hasil
penelitian ini sejalan dengan pendapat Guthrie dan Schuerman (Guthrie, 2010) bahwa efektivitas pengelolaan sekolah juga dapat dilakukan bilamana mendapatkan pasokan energi positif dari localleaders dalam hal mana local leaders yang hadir ke sekolah dan membawa atmosfir positif. Kondisi tersebut akan menjadi lebih baik bilamana kepala sekolah sebagai pemimpin lembaga sekolah memiliki dua hal utama yaitu sumberdaya dan otoritas yang memadai. Schermerhorn, Hunt dan Osborn (Schermerhorn, 2005) juga mengemukakan bahwa localleaders dengan pengaruh dan kekuasaannya dapat hadir ke lembaga pendidikan (sekolah) baik dengan membawa personal power maupun position power yang dimilikinya.

Model Esensi Kepemimpinan Efektif yang dikemukakan oleh Yulk (2003) mendukung kesimpulan ini bahwa kepemimpinan yang efektif adalah pemimpin yang mampu berperan sesuai dengan fungsifungsi yang dimilikinya. Pendapat lain, Newstrom (Newstrom, 2007) juga melihat bahwa baik pemimpin informal maupun pemimpin formal masing-masing memiliki sisi pengaruh (influence) dan kekuasaan (power) yang dapat digunakan dalam mempengaruhi organisasi (termasuk institusi pendidikan). Demikian pula Robbins (Robbins, 1994) justru memandang sisi baik dan buruk dari kekuasaan para pemimpin lokal. Sisi baiknya apabila pemimpin lokal masuk ke institusi pendidikan dengan dukungan dan kepedulian. Sementara sisi buruknya apabila pemimpin lokal menancapkan intervensinya sehingga menjadi kendala bagi berkembangnya otoritas pengelolaan sekolah.

Sebagaimana diketahui bahwa organisasi sekolah melayani multi-klien. Sekolah-sekolah adalah instrumen bagi masyarakat yang lebih luas, sehingga kepala-kepala sekolah memiliki banyak atasan. Atasan-atasan dan klien tersebut dengan caranya masing-masing seringkali membawa atmosfir baru bagi sekolah. Atmosfir positif akan membangun sekolah menjadi sebuah lembaga pendidikan yang efektif dan efisien. Sebaliknya atmosfir negatif akan merendahkan sekolah sehingga seakan-akan berjalan dalam genggaman kekuasaan. Hal ini bisa terjadi karena sekolah adalah target bagi berbagai jenis harapan, pengaruh dan intervensi.

Disebutkan pula dalam Integrative Models of Organization Behaviour,Colquitt, LePine dan Wesson (Colquitt, 2009) bahwa job performance (kinerja) yang dalam hal ini efektivitas pengelolaan sekolah termasuk pada kategori dampak individual mendapatkan 
pengaruh dari learning dan decision making (individual mechanism) yang mendapat pengaruh langsung dari leadership styles and behaviors (group mechanism).

Hasil penelitian terdahulu Paton(Patton, 2005)bahwa kepemimpinan pemimpin informal cenderung berpatokan pada ajaran alam.Alam mengajarkan manusia untuk arif dan damai. Pengambilan keputusan lebih cenderung demokratis dan bentuk interaksi yang digunakan adalah melalui partisipatif sebagaimana proses komunikasi yang dikembangkan melalui komunikasi interaktif. Kingsley (2010), menyimpulkan bahwa pemimpin agama lokal, Tuan Guru adalah aktor-aktor informal kunci (di luar birokrasi) yang memiliki pengaruh yang sangat kuat dan membekas di hati masyarakat Lombok. Hal ini berarti bahwa para Tuan Guru dapat bertindak sebagai penyeimbang dan atau stabilisator dan mediator atas perilaku konflik di masyarakat.

Kedua, fungsi komite sekolah berpengaruh langsung terhadap efektivitas pengelolaan sekolah, dimana fungsi komite sekolah sebagai agen/mitra sekolah berfungsi dalam memberikan saran dan pendapat (advisory), dukungan (supporting), menegakkan fungsi kontrol (controlling) dan dalam menjembatani (mediator) sekolah dengan pihak lain di luar sekolah sehingga berpengaruh langsung terhadap efektifnya pengelolaan sekolah.

Pengaruh fungsi komite sekolah secara langsung terhadap efektivitas pengelolaan sekolah sebagaimana dikemukakan dalam modul Penguatan Kelembagaan Komite Sekolah (Depdiknas, 2006) bahwa Komite Sekolah berfungsi sebagai advisory agency, supporting agency, controlling agency dan sebagai mediator. Melalui implementasi keempat fungsi ini, komite sekolah dapat secara langsung mempengaruhi kepala sekolah dalam mengelola sekolah yang efektif.

Guthrie dan Schuermann (Guthrie, 2010) mengemukakan bahwa keterlibatan komite sekolah (parents and community) tidak hanya terbatas pada hubungan baik sekolah dengan orang tua atau kelompok orang tua saja dalam arti hubungan antara produsen dan konsumen. Hubungan tersebut bisa dalam bentuk pengembangan manajemen sekolah sampai pada bagaimana upaya meningkatkan kualitas hasil yang dicapai oleh siswa (students'achievements) dalam berbagai aspek.Hubungan baik tersebut dapat memberikan pengaruh yang cukup signifikan bagi kepala sekolah dalam upayanya menemukan solusi terbaik bagaimana mengelola sekolah secara efektif. Kepala sekolah dapat memanfaatkan potensi keterlibatan orang tua dan komunitas dalam bentuk perencanaan, proses, output dan bahkan outcome bagi pengelolaan sekolah yang dipimpinnya. Komite sekolah (community members) dapat mendukung kepala sekolah membuat keputusan berbasis kebutuhan sekolah (school-based decision making) yaitu dengan menegakkan tanggung jawab 
sekolah sebagai milik masyarakat atau berorientasi konsumen. Masukan-masukan dari orang tua dan komite sekolah menjadi bahan pertimbangan bagi kepala sekolah dalam membuat keputusan yang mendukung efektifnya kinerja sekolah.

Hasil penelitian terdahulu dan kajian Ausaid Indonesia (2010) dalam laporan khususnya bahwa kehadiran masyarakat di sekolah melalui forum komite sekolah merupakan bentuk partisipasi yang bisa diberikan oleh masyarakat dalam mendukung pendidikan bagi anak-anaknya. Model dukungan tersebut dapat berupa masukanmasukan atau saran tindak, dukungan finansial terbatas, pengawasan yang berwawasan sehingga muncul prinsip transparansi dan akuntabilitas di sekolah serta menjembatani sekolah dengan pihak ketiga (the third party) seperti dunia usaha, dunia industri, serta filantrofi lainnya. Demikian pula hasil penelitian Zaini Arony (Arony, 2005) yang menyimpulkan bahwa kemampuan kepala sekolah dalam mengelola sekolah dasar di Kota Mataram berhubungan erat dengan adanya partisipasi masyarakat yang kuat, pengetahuan kepala sekolah tentang manajemen berbasis sekolah dan gaya kepemimpinan kepala sekolah yang diterapkan.

Ketiga, dukungan virtual team berpengaruh langsung terhadap efektivitas pengelolaan sekolah, dimana dukungan virtual teamturut andil dalam memberikan masukan, arahan petunjuk dan data bagi kepemimpinan sekolah sehingga secara langsung berpengaruh terhadap efektifnya pengelolaan sekolah. Merujuk pada pendapat Powell, Piccoli dan Ives (2004) bahwa terdapat tiga kategori besar yang dapat dilihat dari dukungan virtual, yaitu: input, processes (socio-emotional processes dan task processes) dan Output yaitu melihat kinerja tim dan kepuasan kerja tim. Ketiga rangkaian aktivitas tim virtual ini berpotensi membantu kepala sekolah secara langsung dalam melakukan efektivitas pengelolaan sekolah. Kepala sekolah dalam melaksanakan tugas manajerialnya di sekolah tidak lepas dari komunikasi yang intens dengan berbagai pihak termasuk tim maya yang dikenalnya sehingga fungsi konsultatif dan rujukan. Schermerhorn, Hunt dan Osborn (2005) bahwa adanya harapanrapan kepala sekolah ketika ambigu terhadap sesuatu persoalan.Sifat ambigu ini mungkin saja dikarenakan oleh kurangnya informasi yang memadai tentang sesuatu topik atau banyak dan beragamnya informasi tentang topik tersebut sehingga sulit bagi kepala sekolah untuk menentukan pilihan yang tepat. Di sinilah fungsi tim virtual dalam memberikan dukungan informasi. Yulk (Yulk, 2003) menulis bahwa keterlibatan tim virtual tergolong unik walaupun memang agak sulit menanamkan pengaruh hanya dengan alat eletronik. Namun demikian, bila informasi yang diberikan untuk mempengaruhi cukup rasional dan berkenaan dengan pengetahuan, rasional dan pengalaman yang pernah dihadapi kepala sekolah, maka informasi 
yang diperoleh dapat secara langsung mempengaruhi mindset kepala sekolah untuk membuat sebuah keputusan.

Sebuah penelitian terdahulu yang dilakukan oleh Black (2002) dari Arkansas University menyimpukan bahwa keberadaan Virtual Teammembawa dampak positif yang luar biasa. Jelas terlihat bahwa peran teknologi dalam lingkungan akademik sangat prospektif dan akan berlanjut merubah konsep-konsep pengelolaan pendidikan kita secara dramatis yang semula tradisional menjadi digital dan elektronik. Perkembangan teknologi memberikan alternatif yang signifikan dalam cara orang bekerja sama dalam tim-tim yang solid dan padu. Dinamisasi tim virtual lambat laun akan menggantikan sebagian besar peran tim tatap muka (face-to face team) dalam beberapa aspek penting dan menentukan.

\section{Keempat,pengambilan}

$\begin{array}{llr}\text { Keputusan } & \text { Kepala } & \text { Sekolah } \\ \text { berpengaruh } & \text { langsung } & \text { positif }\end{array}$ terhadap Efektivitas Pengelolaan Sekolah, dimana Pengambilan Keputusan Kepala Sekolah dalam kepemimpinan sekolah berpengaruh langsung terhadap efektifnya pengelolaan sekolah. Pengaruh langsung Pengambilan Keputusan Kepala Sekolah terhadap Efektivitas Pengelolaan Sekolah seperti dikemukakan oleh Hoy dan Miskels (Hoy, 2001) melalui langkahlangkah Pengambilan Keputusan Kepala Sekolah dalam kegiatannya menjalankan organisasi sekolahnya yaitu meliputi: $A$ problem is identified, goals and objectives are established, all the possible alternatives are generated, the consequences of each alternative are considered, all the alternatives are evaluated in terms of the goals and objectives, the best alternative is selected - that is the one that maximizes the goals and objectives, and the decision is implemented and evaluated.Proses pengambilan keputusan dalam organisasi sekolah merupakan langkah-langkah kepala sekolah dalam menafsir masalah dan melakukan keputusan organisasi sekolah dengan cara memeriksa dan mengidentifikasi infomasi secara rasional seraya mengantisipasi dan mengevaluasi segala kemungkinan akibat dari keputusannya.

Ibtisham (1999) mengatakan bahwa di beberapa negara di dunia hendaknya menyadari salah satu faktor penting dalam aspek pendidikan yaitu memposisikan kembali kekuasaan dan tanggungjawab.Sebagaimana dalam konteks otonomi daerah, yaitu urusan pemerintah pusat dan daerah yang juga berlaku bagi diberikannya otoritas yang memadai bagi manajer sekolah agar mengelola sekolahnya secara otonom. Transformasi ini diakibatkan oleh berbagai tuntutan: politik (pengambilan keputusan secara demokratis yang membutuhkan keterlibatan komunitas lokal sebagai stakeholder kunci), sosial (membuat keputusan yang lebih sesuai dengan keinginan masyarakat setempat) dan ekonomi (lebih efektif dan efisien dalam penggunaan sumberdaya sehingga memerlukan kontrol yang memadai 
dari daerah dalam memutuskan pengalokasian sumberdaya).Janis dan Mann (1997) membagi beberapa jenis pola pengambilan keputusan (decision making style) organisasi sekolah yang dilakukan oleh kepala sekolah dalam mengelola lembaga yang dipimpinnya, yaitu pola: pengalaman, konsultatif, fasilitatif, delegatif, kebebasan, selektif, dan komitmen.

Hasil penelitian terdahulu telah dilakukan oleh Madhakolama (2002) yang menyimpulkan bahwa terdapat korelasi positif antara, pertama, kepemimpinan kepala sekolah dan Pengambilan Keputusan Kepala Sekolah. Kedua, komunikasi interpersonal dan Pengambilan Keputusan Kepala Sekolah, dan ketiga, kontrol kepala sekolah dan Pengambilan Keputusan Kepala Sekolah serta terdapat korelasi positif antara ketiga independen variabel terhadap Pengambilan Keputusan Kepala Sekolah.

Kelima, peran local leaders berpengaruh langsung terhadap pengambilan keputusan kepala sekolah, di mana peran local leaders dalam mempengaruhi, mendorong, membimbing, mengarahkan, dan dalam menggerakkan kepemimpinan sekolah berpengaruh langsung terhadap otonomnya Pengambilan Keputusan Kepala Sekolah.

Hasil penelitian yang telah dilaksanakan oleh International Institute for educational Planning yang dimuat dalam IIEP Newsletter Vol. XVIII No. 4 Oktober-Desember (2000) bahwa bilamana ingin melihat kepala sekolah dan guru bekerja maksimal maka Local Leaders (fokus pada local political authority and interest group) hendaknya memberikan otonomi yang memadai kepada kepala sekolah dan guru. Politikus lokal dan kelompok kepentingan juga hendaknya memiliki ide-ide, masukan, opini dan saran tentang apa yang harus dilakukan dan tidak dilakukan oleh sekolah. Namun demikian, menurut hasil penelitian ini, para politikus lokal dan kelompok kepentingan tidak hanya mendukung tetapi juga berlawanan (kelompok penekan/pressure group). Bagi kelompok kedua, walaupun kepala sekolah telah memiliki otonomi tetapi kepala sekolah hendaknya memenuhi berbagai tuntutan lain dari berbagai sisi yang tidak jarang menimbulkan konflik.

Kenyataan yang ada, pengaruh peran local leaders dalam pengambilan keputusan kepala sekolah di Kota Mataram juga tidak sepi dari keterlibatan kelompok kepentingan. Beberapa keputusan yang diambil kepala sekolah hendaknya mengacu pada aturanaturan dinas, Peraturan Walikota, tekanan-tekanan yang diberikan oleh kelompok-kelompok kepentingan baik secara individu maupun kelompok. Kondisi ini memungkinkan kepala sekolah tidak otonom dalam pengambilan keputusan.Bentuk tekanan yang diberikan, tentu saja tidak dapat dikemukakan dalam tulisan ini dan membutuhkan pengkajian lebih lanjut.

Namun

demikian, sebagaimana telah dikemukakan 


\begin{abstract}
sebelumnya bahwa dinamika otonomi daerah membawa konskuensi bagi semakin banyaknya bermunculan orangorang yang merasa berkepentingan dengan sekolah. Tidak terkecuali pemimpin-pemimpin lokal.Kehadiran mereka sejatinya memberikan dukungan maksimal bagi semakin baik, sehat dan kuatnya keputusan yang dibuat oleh kepala sekolah. Alhasil, kehadiran pemimpin lokal justru memberikan kesulitan tersendiri bagi kepala sekolah dalam membuat keputusan. Kekuasaan (power) yang dimiliki oleh para pemimpin lokal, baik pemimpin lokal formal maupun pemimpin lokal informal tidak jarang menjadi pemicu bagi tidak rasionalnya keputusan yang dibuat oleh kepala sekolah. Dalam banyak kasus, pengaruh para pemimpin lokal memaksa kepala sekolah terkadang harus melonggarkan atau bahkan melanggar aturan yang sudah disepakati.
\end{abstract}

Keenam, fungsi komite sekolah berpengaruh langsung positif terhadap pengambilan keputusan kepala sekolah, dimana fungsi komite sekolah sebagai agen/mitra sekolah berfungsi dalam memberikan saran dan pendapat (advisory), dukungan (supporting), menegakkan fungsi kontrol (controlling) dan dalam menjembatani (mediator) sekolah dengan pihak lain di luar sekolah berpengaruh langsung terhadap Pengambilan Keputusan Kepala Sekolah. Guthrie dan Schuermann (Guthrie, 2010) bahwa keterlibatan komite sekolah (parents and community) tidak hanya terbatas pada hubungan baik sekolah dengan orang tua atau kelompok orang tua saja dalam arti hubungan antara produsen dan konsumen. Kehadiran mereka sejatinya memberikan dukungan maksimal bagi semakin baik, sehat dan kuatnya keputusan yang dibuat oleh kepala sekolah. Alhasil, kehadiran komite sekolah tidak jarang menjadi pemicu bagi tidak rasionalnya keputusan yang dibuat oleh kepala sekolah. Dalam banyak kasus, pengaruh komite sekolah memaksa kepala sekolah terkadang harus melonggarkan atau bahkan melanggar aturan yang sudah disepakati.

Fungsi Komite Sekolah dan pengaruhnya terhadap Pengambilan Keputusan Kepala Sekolah di Kota Mataram terjadi pada konteks rapat komite sekolah. Pertimbangan, nasehat dan saran dari komite sekolah sesuai dengan tupoksinya baik mendukung atau pun menolak kebijakan kepala sekolah. Namun demikian, mengingat kepala sekolah adalah salah satu komponen dalam tubuh Komite sekolah, jadi apapun hasil kesepakatan komite sekolah seringkali merupakan hasil keputusan kepala sekolah juga. Perbedaan pendapat hanya akan terjadi dalam rapat komite sekolah. Keputusan akhir yang diambil biasanya akan diaplikasikan oleh kepala sekolah dalam pengambilan keputusannya dan keputusan itu akan menjadi "aman" karena mendapat dukungan dari komite sekolah. Permasalahan justru akan muncul bilamana hubungan kemitraan kepala sekolah dan komite sekolah tidak harmonis. Hal yang terjadi adalah, komite sekolah 
menjadi apatis dan bentuk dukungan yang diberikan hanya terbatas pada tugas-tugas pokoknya komite sekolah saja. Dengan demikian sangat penting bagi lembaga sekolah memiliki komite sekolah yang kuat. Selain mitra yang dapat memberikan fungsifungsi advis dan dukungan juga akan kuat dalam mengontrol dan memberikan mediasi antara sekolah dengan pihak lain.

Kondisi lain yang disinyalir turut melonggarkan keterlibatan komite sekolah dalam memenuhi tugas-tugasnya di sekolah adalah telah tertanamnya anggapan bahwa keterlibatan komite sekolah identik dengan dukungan finansial. Ketika pemerintah mengeluarkan kebijakan pendidikan dasar gratis dengan memenuhi seluruh pembiayaan pendidikan melalui Bantuan Operasional Sekolah, maka masyarakat menganggap bahwa komite sekolah sudah tidak diperlukan lagi. Pemahaman tentang eksistensi komite sekolah yang keliru ini sesungguhnya harus segera diluruskan oleh pemerintah dalam hal ini melalui dinas pendidikan dan dewan pendidikan.

Terakhir, dukungan virtual team berpengaruh langsung positif terhadap pengambilan keputusan kepala sekolah, dimana dukungan virtual team turut andil dalam memberikan masukan, arahan petunjuk dan data bagi kepemimpinan sekolah sehingga secara langsung berpengaruh terhadap Pengambilan Keputusan Kepala Sekolah. Menurut Powell, Piccoli dan Ives (2004) bahwa baik sisi input, processes maupunoutput dari kinerja tim virtual berpotensi membantu kepala sekolah secara langsung dalam pengambilan keputusan yang kuat dan otonom. Kepala sekolah dalam melaksanakan tugas manajerialnya di sekolah tidak lepas dari komunikasi yang intens dengan berbagai pihak termasuk tim maya yang dikenalnya sehingga muncul fungsi konsultatif dan rujukan. Schermerhorn, Hunt dan Osborn (Schermerhorn, 2005) bahwa adanya harapan-rapan kepala sekolah ketika ambigu terhadap sesuatu persoalan.Sifat ambigu ini mungkin saja dikarenakan oleh kurangnya informasi yang memadai tentang sesuatu topik atau banyak dan beragamnya informasi tentang topik tersebut sehingga sulit bagi kepala sekolah untuk menentukan pilihan yang tepat. Di sinilah fungsi tim virtual dalam memberikan dukungan informasi sehingga kepala sekolah dapat membuat keputusan yang tepat.

Sebuah penelitian yang dilakukan oleh Black (2002) bahwa keberadaan virtual teammembawa dampak positif yang luar biasa. Jelas terlihat bahwa peran teknologi dalam lingkungan akademik sangat prospektif dan akan berlanjut merubah konsep-konsep pengelolaan pendidikan secara dramatis yang semula tradisional menjadi digital dan elektronik. Perkembangan teknologi memberikan alternatif yang signifikan dalam cara orang bekerja sama dalam tim-tim yang solid dan padu. Yulk(Yulk, 2003)mengatakan bahwa keterlibatan tim virtual tergolong unik walaupun memang agak sulit menanamkan pengaruh 
hanya dengan alat eletronik. Namun demikian, bila informasi yang diberikan untuk mempengaruhi cukup rasional dan berkenaan dengan pengetahuan, rasional dan pengalaman yang pernah dihadapi kepala sekolah, maka informasi yang diperoleh dapat secara langsung mempengaruhi mindset kepala sekolah untuk membuat sebuah keputusan.

\section{KESIMPULAN DAN SARAN}

Berdasarkan hasil penelitian tersebut dapat disimpulkan bahwa bahwa terdapat pengaruh langsung positif seluruh variabel eksogen terhadap variabel endogen. Implikasinya, pengelolaan sekolah dapat lebih efektif melalui upaya peran positif local leaders, komite sekolah yang menjalankan fungsifungsinya, dukungan dari virtual team, dan pengambilan keputusan kepala sekolah yang kuat dan otonom baik secara langsung maupun tidak langsung. Hal ini akan memberikan implikasi teoretis dan implikasi kebijakan pada pengelolaan sekolah yang efektif di Kota Mataram. Sehingga disarankan agar pemerintah Kota Mataram selain membuat grand design pendidikan di kota Mataram, juga memperhatikan sungguh-sungguh otoritas kepala sekolah dalam pengambilan keputusan, memberikan akses bagi peran positif local leaders, memfungsikan komite sekolah sebagai partner harmonis sekolah, memanfaatkan dukungan virtual team melalui pemberdayaan sistem komunikasi dan informasi serta penguatan kapasitas kepala sekolah dalam pengambilan keputusan.

\section{DAFTAR PUSTAKA}

Allison, G. a. (1999). Essence of Decision: Explaining the Cuban Missile Crisis (2nd Edition ed.). Addison Wesley.

Arony, Z. (2005). Studi Hubungan antara Partisipasi Masyarakat Pengetahuan Kepala Sekolah dan Kepimpinan Kepala Sekolah dengan Kemampuan Mengelola Sekolah pada SDN di Kota Mataram. Jakarta: Manajemen Pendidikan Universitas Negeri Jakarta.

Colquitt, J. L. (2009). Organizational Behavior: Improving Performance, Commitment in the Work Place (Second Edition ed.). New York: McGraw-Hill Companies, Inc.

Covey, S. R. (1994). Seven Habit Maturity Continum, Seven Habits of the Highly Effective People.

David, G. T. (2006). Professional Development for Leaders and Managers of Self Governing Schools. Springer.

Davis, K. a. (1998). Perilaku dalam Organisasi. Jakarta: Erlangga.

Depdiknas. (2006). Modul 1: Penguatan Kelembagaan Komite Sekolah. Jakarta: Depdiknas.

Guthrie, J. W. (2010). Successful School Leadership: Planning, Politics, Performance and Power. USA: Pearson Education Inc. 
Hess, P. d. (1996). Management: Responsibility for Performance. New York: McGraw-Hill, Inc.

Hoy, W. K. (2001). Educational Administration: Theory, research and Practice (Sixth edition ed.). New York: The McGraw-Hills Companies, inc.

Kerslake, R. (2007). Turnaround Leaderships. Solace Foundation Imprint.

Kingsley, J. (2010). Tuan Guru, Community and Conflict in Lombok, Indonesia. Thesis for the Degree for Doctor of Philosophy of Melbourne University.

Luthans, F. (1995). Organization Behavior. New York: McGraw-Hills.

Madhakolama. (2002). Pengambilan Keputusan Kepala Sekolah: Studi Korelasional Antara Kepemimpinan Kepala Sekolah, Komunikasi Interpersonal dalam Organisasi Sekolah dan Kontrol Kepala Sekolah dengan Pengambilan Keputusan Kepala Sekolah. Jakarta: Manajemen Pendidikan UNJ.

Mondy, R. W. (1988). Management: Concept and Practices. Boston: Allyn and Bacon, Inc.

Newstrom, J. W. (2007). Organization Behavior: Human Behavior at Work. New York: McGraw-Hill. Inc.

Patton, A. (2005). Gaya digunakan Pemimpin Informal (Kepala Adat) di Daerah Perbatasan Kabupaten Malinau Kalimantan Timur. Jurnal Ekonomi dan Manajemen, Volume 6 Nomor 3 Tahun 2005.

Porter, A. G. (2006). A Framework for the Assessment of Learning-Centered Leadership. New York: Wallace Foundation.

Robbins, S. P. (1994). Organizational Behavior, Concepts, Controversies and Applications. Prentice-Hall., inc.

Roe, T. L. (1986). Principalships. New York: Macmillan Publishing Company.

Salusu, J. (1996). Pengambilan Keputusan Strategik untuk Organisasi Publik dan Organisasi Non Profit. Jakarta: Grasindo.

Schermerhorn, J. J. (2005). Organizational Behavior (ninth edition ed.). PrenticeHall.

Steers, R. M. (1980). Organization Effectiveness: A Behavioral View. (M. Jamin, Trans.) Jakarta: LPPM dan Airlangga.

Stoner, J. A. (1996). Manajemen. (A. S. Sayak, Trans.) Jakarta: Prenhalindo.

Yulk, G. (2003). Leadership in Organization (Fifth Edition ed.). New York: Prentice Hall, inc. 